\title{
ІСТОРІЯ ПРИРОДОЗНАВСТВА
}

УДК 636.2.082:009:001

Апостол М.В.

\author{
ДІЯЛЬНІСТЬ АКАДЕМІКА М. В. ЗУБЦЯ \\ В КОНТЕКСТІ СТАНОВЛЕННЯ ІНСТИТУТУ \\ РОЗВЕДЕННЯ І ГЕНЕТИКИ ТВАРИН
}

Висвітлено внесок доктора сільськогосподарських наук, професора, академіка НААН М. В. Зубия в становлення Інституту розведення і генетики тварин НААН, здобуття ним статусу провідного науково-методичного $i$ координаційного центру в галузі тваринництва. Обтрунтовано, щцо вченим закладено фундамент для розвитку наукових досліджень з проблем розведення та селекиії, генетики та біотехнології, становлення сучасної теорії породотворення в тваринництві. За його керівництва створено низку спеціалізованих порід великої рогатої худоби молочного $і$ м'ясного напрямів продуктивності, що сприяло зростанню конкурентоспроможності вітчизняного тваринництва. М.В.Зубием на базі інституту засновано одну із найбільш авторитетних наукових шкіл з селекиії м'ясної худоби в Україні.

Ключові слова: тваринництво, скотарство, селекція, генетика, біотехнологія, порода сільськогосподарських тварин, наукова школа.

У становлення та розвиток наукових основ тваринництва в Україні значний внесок зроблено Інститутом розведення і генетики тварин імені М.В.Зубця НААН. Ученими інституту здійснюється правове і нормативне забезпечення функціонування, розроблення і впровадження систем селекції у молочному і м'ясному скотарстві на популяційному (загальнопородному і міжпородному) рівні їх організації. Розроблено методологію практичного збереження генофонду порід in situ та ex situ у контексті функціонування Національного надбання - Банку генетичних ресурсів тварин і світової проблеми збереження біологічного різноманіття. Сформульовано основи функціонування і формування загальнодержавної інформаційної бази даних у молочному i м'ясному скотарстві. Здійснюється науково-методичне i координаційне забезпечення створення та селекційно-генетичного поліпшення вітчизняних порід, типів, ліній та родин сільськогосподарських тварин.

Узагальнення історичного досвіду 3 удосконалення технологій виробництва продукції тваринництва є особливо актуальним на сучасному етапі, коли здійснюється пошук ефективних шляхів вирішення проблеми безпеки харчування населення, зростання конкурентоспроможності вітчизняного тваринництва.

Окремі питання становлення Інституту розведення і генетики тварин знайшли відображення в наукових працях В. П. Бурката, І. С. Бородай та ін. $[3,4,8]$. Однак до цього часу не проведено комплексного узагальнення внеску в оптимізацію його діяльності, здобуття статусу провідного 
галузевого науково-дослідного центру доктора сільськогосподарських наук, професора, академіка НААН М. В. Зубця. 3 огляду на зазначене, це завдання висувалося на перший план при проведенні даного дослідження. Автором використано історичні (порівняльно-історичний, предметнохронологічний), загальнонаукові (аналіз, синтез, логічний) та джерелознавчий методи. Методологія дослідницького пошуку грунтується на застосуванні системно-історичного підходу.

Варто відмітити, що Інститут розведення і генетики тварин НАAН організовано за постановами Державного Комітету Ради Міністрів СРСР по науці і техніці від 8 квітня 1975 року № 21 та Ради Міністрів УРСР від 10 вересня № 429 на базі Київської дослідної станції тваринництва «Терезине» та Центральної дослідної станції штучного осіменіння сільськогосподарських тварин. Від початку свого існування інститут виконував функцію головного науково-методичного та координаційного центру з проблем селекції, генетики та біотехнології у тваринництві. Враховуючи це, його діяльність спрямовували на вирішення низки завдань:

- $\quad$ розробку теоретичних та практичних основ розведення та селекції сільськогосподарських тварин;

- удосконалення існуючих та створення нових високопродуктивних порід і типів худоби;

- запровадження програм великомасштабної селекції на основі сучасних досягнень популяційної генетики, імуногенетики, цитогенетики, клітинної та генної інженерії, новітніх біотехнологій;

- впорядкування організаційних форм i методів селекційноплемінної роботи за різних умов господарювання;

- обгрунтування ефективних методів оцінки тварин за продуктивними та племінними якостями, раціональне використання поліпшувачів;

- запровадження автоматизованих систем управління селекційним процесом у тваринництві;

- освоєння прогресивних методів і форм збереження та раціонального використання племінних ресурсів сільськогосподарських тварин.

Відповідно до окреслених завдань сформовано структуру інституту, яка поєднала відділення розведення молочної та м'ясної худоби, генетики i біотехнології, кожне 3 яких у свою чергу було представлене рядом лабораторій та секторів. При інституті також функціонували відділи відтворення, економіки, аспірантури та науково-технічної інформації. Для розширення масштабів роботи відкрито філії у Дніпропетровську, Львові та Черкасах, на базі яких наразі створено потужні науково-дослідні інститути [4].

Істотний внесок у становлення інституту здійснив його фундатор, перший 
заступник голови Ради Міністрів УРСР, талановитий організатор аграрного виробництва та вчений-селекціонер - П. Л. Погребняк. Разом із першим директором інституту В. Ю. Недавою, який очолював заклад більше десяти років, вони доклали чимало зусиль до створення належної матеріальнотехнічної бази, організації плідної науково-дослідної роботи, виховання гідного колективу науковців. У 1991-1996 роках ствердження Інституту розведення і генетики тварин як головного науково-методичного центру України з проблем генетики, селекції і біотехнології у тваринництві було реалізоване завдяки послідовній i цілеспрямованій діяльності його директора М. В. Зубця [8].

Учений сприяв оптимізації структури установи, зміцненню іiі наукового потенціалу, матеріально-технічної та племінної бази, розширенню наукової тематики та розгортанню плідної науково-дослідної роботи. Саме в цей час було активізовано творчі пошуки учених інституту 3 кардинального перетворення вітчизняного генофонду порід, отримали більшу спрямованість дослідження 3 генетики i біотехнології, які склали теоретичну основу для розвитку селекції сільськогосподарських тварин. Це сприяло остаточному ствердженню інституту як головного науковометодичного центру з проблем розведення і генетики тварин, набуттю статусу лідера вітчизняної зоотехнічної науки [9].

Під керівництвом академіка М. В. Зубця колектив брав участь в розробці програм 3 розведення i генетики тварин i безпосередньо проводив дослідження за двома фундаментальними завданнями. У результаті була розроблена принципово нова теорія породотворного процесу в скотарстві, яка базується на оригінальних, вперше запропонованих концепціях [5].

За період 1991-1996 років було створено і апробовано дві спеціалізовані молочні породи, а саме українські червоно-рябу і чорно-рябу, а також дві м'ясні породи - українську і волинську. За своїми основними господарськи корисними ознаками вони не поступаються європейським аналогам, а за такими, як плодючість, тривалість господарського використання перевершують їх. Новітня теорія породотворення була визнана у державному масштабі і відзначена премією України в галузі науки і техніки [2].

Під керівництвом М. В. Зубця здійснювалась комплексна науководослідна робота спільно 3 інститутами і дослідними станціями системи Національної академії аграрних наук України, а також було налагоджено співробітництво з галузевими вищими навчальними закладами. У результаті спільних досліджень були узагальнені теоретичні і методичні підходи 3 використання імуногенетичних маркерів при створенні нових молочних $\mathrm{i}$ м'ясних порід великої рогатої худоби. Запропоновано методи контролю генетичної консолідованості і спрямованості селекційного процесу при схрещуванні за комплексом поліморфних генетичних систем. Саме в цей час були запроваджені біотехнологічні підходи до селекційного процесу в 
тваринництві, а також вперше в Україні були розроблені наукові і методичні основи раціонального розміщення i використання племінних ресурсів $\mathrm{i}$ комплексна програма для управління селекційним процесом за допомогою ПЕОМ [4].

М. В. Зубець привернув увагу науковців до проблеми дослідження i використання генофонду великої рогатої худоби, яка в подальшому перетворилась на самостійний напрям з оцінювання і збереження генофонду сільськогосподарських тварин як елемент глобальної проблеми зі збереження біорізноманіття тваринного світу [1, арк. 3-5]. Інститут з 2006 р. $\epsilon$ головною установою, яка координує виконання програми наукових досліджень НААН «Збереження генофонду». На $\dddot{11}$ реалізацію спрямовувалося створення Банку генетичних ресурсів тварин з філіями у регіонах України, віднесеного до наукових об'єктів, що становлять національне надбання (розпорядження Кабінету Міністрів України від 19 серпня 2002 р. № 472-р.). Результатом реалізації завдань програми «Збереження генофонду» є членство України з 2009 р. у Європейському регіональному центрі генетичних ресурсів тварин (European Regional Focal Point for Animal Genetic Resources, ERFP) при FAO.

Колективом науковців під керівництвом М. В. Зубця, були розроблені нові теоретичні, методичні i організаційні основи створення i вдосконалення молочної худоби на основі відтворного схрещування, методи аналізу інбридингу, вивчена його ефективність при розведенні молочної худоби, проведений теоретичний аналіз генетико-популяційних процесів при відтворювальному схрещуванні, визначені механізми зв'язку генетичних маркерів 3 продуктивністю і типом тварин, встановлена породна мінливість показників природної резистентності. Ці принципи і методи селекції були застосовані як під час створення нових молочних порід, так i при подальшому їх вдосконаленні [2, арк. 11-15].

В селекційному процесі знайшли застосування схеми селекції помісних бугаїв 3 використанням генофонду кращих порід світу, імуногенетичне маркування спадкового матеріалу родоначальників і продовжувачів ліній та інформаційне забезпечення селекційного процесу 3 оцінюванням i використанням наявних племінних ресурсів. Основним принципом створення нових порід стало комплексне оцінювання генотипових особливостей тварин на всіх етапах селекційного процесу з урахуванням генетико-популяційних параметрів, оцінювання генотипів плідників i контроль спрямованості селекційного процесу за спадково зумовленими поліморфними системами. Ще в ті роки академік М. В. Зубець наголошував на необхідності спрямовувати генетичні дослідження на вирішення селекційних завдань, що згодом одержало продовження під назвою «геномна селекція» 3 переважним використанням ДНК-маркерів. Набула першорядної уваги проблема інтегрального оцінювання і відбору молочної худоби за природною резистентністю організму [6]. 
На базі інституту М. В. Зубцем засновано наукову школу «Селекція м'ясної худоби», де на принципах творчої співдружності вчених та спадкоємності поколінь знайшли ствердження і розвиток його кращі наукові традиції, ідеї та підходи. В активі його наукової школи 11 докторів та 18 кандидатів сільськогосподарських наук. Серед його учнів відомі вчені, доктори сільськогосподарських наук: І.П.Петренко, О.М.Жукорський, Ю. П. Полупан, І. В. Гузєв, В. П. Бородай, К. В. Копилов, В. А. Вергунов та ін. [3].

Згідно постанови Президії Національної академії аграрних наук України (протокол № 18 від 25 вересня 2014 р.) Інституту розведення і генетики тварин НААН присвоєно ім'я академіка М. В. Зубця. Колектив інституту продовжує започатковані ним наукові пошуки 3 удосконалення вітчизняного генофонду сільськогосподарських тварин у контексті сучасних перетворень. Таким чином, доктор сільськогосподарських наук, професор, академік М. В. Зубець зробив вагомий внесок у становлення Інституту розведення і генетики тварин НААН, здобуття ним статусу провідного галузевого науково-дослідного центру у тваринництві. Здобутком вченого $\epsilon$ зміцнення матеріально-технічної бази установи, розширення тематики науково-дослідних робіт. За його керівництва набули актуальності дослідження з селекції, генетики та біотехнології тваринництва, збереження генофонду сільськогосподарських тварин. На базі інституту розроблено основи сучасної теорії і методології селекції у тваринництві, що сприяло кардинальному перетворенню вітчизняного генофонду. При Інституті розведення і генетики тварин М. В.Зубцем засновано одну із найбільш авторитетних наукових шкіл з селекції м'ясної худоби в Україні.

\section{Джерела та література}

1. Архів Інституту розведення і генетики тварин імені М.В.Зубця НААН. - Звіт про науково-дослідну роботу (заключний за 1991-1995 роки). К.- Чубинське, 1996. - 456 арк.

2. Архів Інституту розведення і генетики тварин імені М.В.Зубця НААН. - Звіт про науково-дослідну роботу (заключний за 1996-2000 роки). Чубинське, 2001. - 505 арк.

3. Бородай I. С. Наукова школа академіка М. В. Зубця: програма діяльності та здобутки / І. С. Бородай // Розведення і генетика тварин : міжвід. тем. наук. зб. / ІРГТ ім. М.В.Зубця НААН, НААН - К., 2015. - Вип. 49. - С. $13-19$.

4. Буркат В. П. Нариси з історії інституту: монографія / В. П. Буркат, I. С. Бородай. - К.: Аграрна наука, 2008. - 556 с.

5. Гладій М. В. Академік М. В. Зубець - талановитий учений, організатор, політичний і громадський діяч / М. В. Гладій // Розведення і генетика тварин: міжвід. тем. наук. зб. / НААН, ІРГТ. - Вип. 49. - К., 2015. - С. 6-13. 
6. Єфіменко М. Я. Зубець Михайло Васильович / М. Я. Єфіменко // Вчені-селекціонекри у тваринництві / УААН; наук. ред.: М. В. Зубець, В. П. Буркат. - К. : Аграрна наука, 1997. - С. 59-62. - («Українські вченіаграрії XX ст.»; кн. 1).

7. Зубець Михайло Васильович: біобібліогр. покажч. наук. пр. за 19662012 роки / НААН, ННСГБ, ІРГТ; уклад. В. А. Вергунов, М. М. Зубець, Т. Ф. Дерлеменко, О. П. Анікіна, І. С. Бородай, Л. А. Кириченко ; наук. ред. В. А. Вергунов. - 3-тє вид., перероб. і доп. - К., 2014. - 372 с. - (Біобібліогр. сер. «Академіки Нац. акад. аграр. наук України» / НААН, ННСГБ).

8. Інститут розведення i генетики тварин / УААН, ІРГТ; уклад.: М. Я. Єфіменко, І. В.Гузєв, Л. О. Бегма та ін. ; відпов. за вип. Ю. В. Мільченко, С. М. Рясенко, І. С. Бородай. - Чубинське, 2004. - 83 с.

9. Полупан Ю. П. Академік Михайло Васильович Зубець (спогади про Вчителя) / Ю. П. Полупан // Зубець Михайло Васильович : бібліографічний покажчик наукових праць за 1966-2012 роки. - К. : ННЦ «IAЕ», 2014. - С. $68-75$.

Апостол М. В. Деятельность академика М. В. Зубца в контексте становления института разведения и генетики животных.

Освещен вклад доктора сельскохозяйственных наук, профессора, академика НААН М. В. Зубиа в становление Института разведения и генетики животных НААН, достижения статуса ведущего научно-методического и координационного иентра в отрасли животноводства. Обосновано, что ученым заложен фундамент для развития научных исследований по проблеме разведения и селекции, генетики и биотехнологии, становления современной теории породообразования в животноводстве. Под его руководством создан ряд спещиализированных пород большого рогатого скота молочного и мясного направлений продуктивности, что способствовало росту конкурентоспособности отечественного животноводства. М. В. Зубияом на базе института основано одну из наиболее авторитетных научных икол по селекции мясного скота в Украине.

Apostol M. V. Activities of academician M. V. Zubets in the context of the formation of the Institute of Animal Breeding and Genetics.

The contribution of doctor of agricultural sciences, professor, academician of NAAS M. V. Zubets to the establishment of the Institute of Animal Breeding and Genetics of NAAS, achieving the status of the leading scientific, methodical and coordination center in the animal husbandry was highlighted. It is proved that the scientists laid the foundation for the development of researches on the problem of rearing and breeding, genetics and biotechnology, the formation of the modern theory of breed formation in animal husbandry. Some of specialized breeds of cattle of milk and beef direction of productivity were created under his leadership thereby increasing the competitiveness of domestic livestock. M. V. Zubets organized one of the most prestigious schools of breeding beef cattle in Ukraine on the basis of the Institute.

Keywords: animal husbandry, cattle husbandry, breeding, genetics, biotechnology, breed of farm animals, scientific school. 